\title{
COMBINING ABILITY AND GENE ACTIONS FOR GLUTEN RHEOLOGICAL TRAITS OF "LINE×TESTER" BREAD WHEAT HYBRIDS
}

\author{
Imren KUTLU ${ }^{1 *}$, Yasar KARADUMAN² \\ ${ }^{1}$ Eskisehir Osmangazi University, Faculty of Agriculture, Department of Biosystem Engineering, \\ Eskisehir, TURKEY \\ ${ }^{2}$ Eskisehir Osmangazi University, Faculty of Agriculture, Department of Food Engineering, Eskisehir, \\ TURKEY \\ *Corresponding author: ikutlu@ogu.edu.tr
}

Received: 30.07 .2020

\begin{abstract}
The fast and reliable measurement techniques in determining bread-making quality such as GlutoPeak parameters is need in a cereal quality breeding programs. Therefore, this study intended to investigate gene actions in the inheritance of gluten rheological properties measured by Glutopeak tester in 28 hybrids of "Line×Tester" bread wheat and their 11 parents based on knowledge of combining ability. There was a prominence of non-additive gene effects for all the traits examined. Well-performed parents such as DH20 and Harmankaya-99 were good combiners for almost all examined traits. "DH16×Bezostaja-1", "DH20×Bezostaja1", "DH20×Harmankaya-99", "DH21×Altay-2000", and "DH22×Kate A-1" were promising combinations based on their SCA effects. There may be an opportunity to select the best genotypes in the $F_{2}$ generation for protein rate, sedimentation value and GlutoPeak parameters such as peak maximum time (PMT) and maximum torque (AM and PM) considering the little increase in narrow sense heritability. This first report, which sheds light on the genetic analysis of GlutoPeak parameters, should be supported by studies that will examine the Glutopeak properties in different segregation generations of hybrids with different originated parents.
\end{abstract}

Keywords: Combining ability, end-use quality, quality breeding, gluten strength

\section{INTRODUCTION}

For many years, the main theme of common wheat (Triticum aestivum L.) breeding programs has been the development of new varieties with high yield and quality. A breeder's primary task is to provide both high-yielding genotypes for growers and high-quality products for consumers. Certainly, the yield has always been and will be the main target of plant breeding; however, the selection is mostly done for quality nowadays, especially by phenotyping and relying on principal cereal chemistry and rheology. Improving the bread making quality of wheat varieties is a process that needs to be examined for some parameters such as protein ratio, gluten quality, sedimentation value, rheological properties, and the contribution of selection to be made in early generations is important. Bread-making capacity is mostly based on the protein amount and flour quality (Hruskova and Famera, 2003). Therefore, it is essential to detect the gluten properties as the wheat flour strength is closely associated with gluten content and quality (Jirsa and Hruskova, 2005). Gluten plays a key role in producing the peculiar baking quality of wheat by supplying water absorption capacity, viscosity, elasticity, and cohesiveness in a dough (Wieser, 2007). Thus, if the protein or gluten content is not known, it is impossible to completely characterize the wheat flour quality. Also important to the analysis is determining the sedimentation value, which shows a correlation with gluten content, loaf volume, and baking quality (Hruskova and Famera, 2003). The protein content, wet and dry gluten, and the rheological properties of flour should be defined to determine a suitable improved variety for the bakery industry (Baslar and Ertugay, 2011).

Furthermore, several rheological tests, such as the farinograph, extensigraph, mixograph, and alveograph are used to characterize wheat processing and bread-making quality and have become significant measurements for wheat grain and flour quality (Gabriel et al., 2017). Rheological tests indicated relative dough strength are not ideal as fast screening methods to recognize the flour gluten strength at the early stages of wheat breeding because a lot of milled grain samples are needed for these tests and the throughput is limited (Wang et al., 2017). For this reason, breeders are seeking for a way to enable 
quality testing of wheat genotypes in the early stages of breeding programs using limited samples. GlutoPeak is currently used as a fast and reliable method to evaluate rheologically end-use quality traits in a shorter period and using a small-scale sample (Rakita et al., 2018). GlutoPeak tester measures the aggregation behavior of gluten and quickly provides information on gluten quality, flour-water absorption, dough-mixing stability indicators, tenacity, and extensibility (Fu et al., 2017). Bouachra et al. (2017) reported that GlutoPeak tester can be used to predict the bread volume, and the best estimation of loaf volume can be obtained with Brebender equivalent at maximum torque (BEM) value measured $15 \mathrm{~s}$ before the maximum torque and protein content.

Quality tests that require a small amount of flour such as the GlutoPeak are now popular with breeders for selection in the early generations (Sissons, 2016). In recent years, the growing interest in studies on GlutoPeak tests has led to its widespread popularity. However, these studies are mostly limited to the optimization of the test, its correlation with other quality characteristics, and evaluation of different varieties (Marti et al., 2015; Bouachra et al., 2017; Kutlu et al., 2017; Rakita et al., 2018; Wang et al., 2017). Especially in the early stages of breeding programs, the selection success could be increased by determining the genetic parameters of GlutoPeak traits, protein content, gluten content, and sedimentation value.

"Line×Tester" analysis is an improved form of the "top-cross" method for the determination of appropriate parents and hybrids of important selection characters as well as the efficient use of the information to be obtained in breeding programs (Kempthorne, 1957). In the method, two groups of genotypes called line and tester are used. It is desired to test the studied characters of the lines that are genetically homozygous. The testers are selected from high-yielding and high-quality cultivars that are well adapted to the region. Each of the testers is hybridized with the lines and hybrid progeny is obtained as the number of "Lines $\times$ Testers". In the population created with this method, it is intended to estimate the different types of gene effects and heritability degrees by obtaining information about general and specific combining abilities.

The study aimed (1) to evaluate 28 "Line×Tester" bread wheat crosses and their 11 parents in terms of basic quality traits and GlutoPeak parameters, (2) to estimate the gene effects that plays a role in the heritability of examined characteristics, and (3) to determine the proper parents and promising crosses.

\section{MATERIAL AND METHODS}

\section{Plant material and experimental design}

In this study, seven doubled haploid (DH) wheat lines were crossed with four cultivars (Altay-2000, Bezostaja-1, Harmankaya-99, Kate A-1) by applying the "Line×Tester" crossing scheme. The pedigrees of the $\mathrm{DH}$ lines were like this: 33IBSWN-S-244 / Mufitbey for DH6, DH18, DH19,
DH20, DH21 and DH22; Tosunbey / Mufitbey for DH16. The $\mathrm{DH}$ lines were improved in the $\mathrm{F}_{2}$ generation of the hybrids that are given pedigrees and have different genotypic traits. $F_{1}$ plants of these 28 hybrids and their 11 parents were grown in a randomized complete block design with three replications during the 2015-2016 growing season. $\mathrm{F}_{2}$ plants of these 28 hybrids and their 11 parents were grown in the 2016-2017 growing season at Eskisehir Osmangazi University Agriculture Faculty research areas, Eskisehir, Turkey. The plots consisted of four rows, which were $1 \mathrm{~m}$ long with 20 plants. The distance between rows was $30 \mathrm{~cm}$. Standard ones were used for breeding programs in irrigation and fertilization applications. The soil of experimental area contains $1.2 \%$ organic matter and $9.6 \%$ lime; it is salt-free, clayey and slightly alkaline ( $\mathrm{pH}$ 7.9-8.3). The total precipitation, average temperature and average humidity were 299.0 $\mathrm{mm}, 10.01{ }^{\circ} \mathrm{C}$ and $74.4 \%$ in the $2015-2016$ growing season, while they were $289.4 \mathrm{~mm}, 8.63^{\circ} \mathrm{C}$ and $73.3 \%$ in the 2016-2017 growing season, respectively. The harvest was done when the plants in each plot reached maturity, and first cleaned using the Buhler Labofix 90 mini-cleaner (Brabender, Duisburg, Germany). Grain samples were milled to whole-wheat flours on an ultra-centrifugal mill (Retsch ZM 200, Germany) equipped with a $0.5 \mathrm{~mm}$ sieve. Thus, ground grain samples were prepared for the analysis of some quality characteristics and GlutoPeak properties stated below.

\section{Quality traits}

The protein rate (PR), wet gluten rate (WG), dry gluten rate (DG) (\%) was determined in a NIR spectroscopy device (NIR 6500, Foss, Hillerod, Denmark), which was calibrated by bread wheat whole grain samples, according to AACC method 39-01.01 (AACC, 2010). As for the SDS sedimentation value, lactic acid, sodium dodecyl sulphate (SDS), bromophenol blue, and flour were mixed, and the suspension prepared with the particles after 14 minutes rinsing process were determined by measuring the collapsed part volume, in milliliters (Pena et al., 1990).

\section{GlutoPeak tests}

The gluten aggregation properties of whole-wheat flour samples were measured by the GlutoPeak device (Brabender, Duisburg, Germany). Initially, $8 \mathrm{~g}$ of wholewheat flour sample was weighed and dispersed in calcium chloride solution with $9 \mathrm{~g}$ of $0.5 \mathrm{~mol} \mathrm{~L}^{-1}$. Meanwhile the liquid to solid ratio was kept at 1.26 and the flour moisture was $14 \%$ (Marti et al., 2015). The measurements were performed with $34^{\circ} \mathrm{C}$ sample temperature, $1900 \mathrm{rpm}$ rotation speed and $600 \mathrm{~s}$ measure times. Maximum torque (BEM in $[\mathrm{BU}]$ ), torque $15 \mathrm{~s}$ before maximum (AM in $[\mathrm{BU}])$, torque $15 \mathrm{~s}$ after maximum (PM in [BU]), peak maximum time (PMT in [s]), alveograph energy (AE was calibrated classical alveograph method in [arbitrary units (AU)] and water absorption (WA was calibrated classical farinograph method as \%) was automatically provided by the software GlutoPeak (version 2.0.0). The measurements were done three parallels for each replicates. 


\section{Statistical analyses}

The "Line×Tester" analysis and its components, general combining ability (GCA), specific combining ability (SCA), GCA / SCA ratio, broad $\left(\mathrm{H}^{2}\right)$, and narrowsense heritability $\left(h^{2}\right)$, were estimated by AGD-R ver. 4.0 software released by CIMMYT (Rodríguez et al., 2015). $F_{1}$ and $F_{2}$ generations were analyzed separately. The scatter plot graphs based on GCA, SCA and mean values of parents and hybrids were drawn by IBM SPSS 20 software program.

\section{RESULTS AND DISCUSSION}

"Line $\times$ Tester" variance analyze and determination of gene action

Table 1 presents "Line×Tester" variance analysis and genetic components for each character of the genotype and hybrid combinations. When the "Line $\times$ Tester" variance analysis of the traits was examined, observed significant variation indicates that examined genotypes (parents and hybrids) had different genetic backgrounds. The data suggested that the expression of the traits in the hybrids varied according to the parental combination (Nathan et al., 2011).

Table 1. "Line×Tester" variance analysis and genetic components for each character of genotype and hybrid combinations

\begin{tabular}{|c|c|c|c|c|c|c|c|c|c|c|c|c|}
\hline SOV & DF & & PR & SDS & WG & DG & BEM & PMT & $\mathbf{A M}$ & $\mathbf{P M}$ & $\mathbf{A E}$ & WA \\
\hline \multirow{2}{*}{ Replication } & \multirow{2}{*}{2} & $\mathrm{~F}_{1}$ & 1.16 & 0.22 & 1.32 & 0.30 & $11.65^{* *}$ & $6.83^{\text {** }}$ & 1.66 & 2.53 & $7.34^{* * *}$ & $5.63^{* *}$ \\
\hline & & $\mathrm{F}_{2}$ & $4.46^{*}$ & 1.64 & 1.79 & $6.32^{* *}$ & 0.84 & 1.77 & 0.79 & 1.44 & 0.10 & 0.47 \\
\hline \multirow{2}{*}{ Genotypes } & \multirow{2}{*}{38} & $\mathrm{~F}_{1}$ & 0.70 & $2.34^{* *}$ & $2.84^{* *}$ & $4.27^{* *}$ & $7.17^{* *}$ & $15.40^{* *}$ & $6.28^{* *}$ & $6.64^{* *}$ & $16.79^{* *}$ & $1.82^{*}$ \\
\hline & & $\mathrm{F}_{2}$ & $2.25^{* *}$ & $1.60^{*}$ & $2.11^{* *}$ & $2.53^{* *}$ & $1.60^{*}$ & 1.41 & 0.69 & $1.91^{* *}$ & $2.04^{* *}$ & 1.37 \\
\hline \multirow{2}{*}{ Parents } & \multirow{2}{*}{10} & $\mathrm{~F}_{1}$ & 0.70 & 1.26 & 1.13 & $2.24^{*}$ & $8.05^{* *}$ & $33.40^{* *}$ & $10.10^{* *}$ & $8.26^{* *}$ & $15.96^{* *}$ & 1.70 \\
\hline & & $\mathrm{F}_{2}$ & $2.00^{*}$ & $2.09^{*}$ & $2.18^{*}$ & $2.65^{\text {** }}$ & 1.80 & $2.20^{*}$ & 0.71 & $2.87^{* *}$ & $2.26^{*}$ & 1.26 \\
\hline \multirow{2}{*}{ Hybrids } & \multirow{2}{*}{27} & $\mathrm{~F}_{1}$ & 0.72 & $2.24^{* *}$ & $3.56^{* *}$ & $5.18^{* *}$ & $5.15^{* *}$ & $9.25^{* *}$ & $5.07^{* *}$ & $4.83^{* *}$ & $14.66^{* *}$ & 1.61 \\
\hline & & $\mathrm{F}_{2}$ & $2.42^{* *}$ & 1.29 & $2.16^{* *}$ & $2.52^{* *}$ & 1.39 & 1.17 & 0.65 & 1.60 & $1.79^{*}$ & 1.44 \\
\hline \multirow{2}{*}{ Parents vs Hybrids } & \multirow[b]{2}{*}{1} & $\mathrm{~F}_{1}$ & 0.01 & $15.88^{* *}$ & 0.43 & 0.18 & $53.00^{* *}$ & 1.33 & 0.71 & $39.40^{* *}$ & $82.58^{* *}$ & $8.72^{* *}$ \\
\hline & & $\mathrm{F}_{2}$ & 0.14 & $5.15^{*}$ & 0.08 & 1.31 & $5.20^{*}$ & 0.04 & 1.71 & 0.65 & $6.43^{*}$ & 0.71 \\
\hline \multirow{2}{*}{ Lines } & \multirow{2}{*}{6} & $\mathrm{~F}_{1}$ & 1.01 & 1.96 & 0.17 & 0.39 & 1.83 & 1.17 & 0.31 & 1.95 & 1.58 & 1.01 \\
\hline & & $\mathrm{F}_{2}$ & 1.12 & 2.09 & 1.46 & 2.49 & 1.74 & 1.23 & 0.87 & 1.11 & 1.74 & 1.55 \\
\hline \multirow{2}{*}{ Testers } & \multirow[b]{2}{*}{3} & $\mathrm{~F}_{1}$ & 1.99 & 0.53 & 0.87 & 0.49 & 0.42 & 0.60 & 0.55 & 2.10 & 1.38 & 1.12 \\
\hline & & $\mathrm{F}_{2}$ & 0.51 & 1.52 & 0.36 & 0.42 & 0.40 & $3.48^{*}$ & 2.17 & 0.53 & 0.40 & 0.50 \\
\hline \multirow{2}{*}{ Line $\times$ Tester } & \multirow{2}{*}{18} & $\mathrm{~F}_{1}$ & 0.65 & $1.93^{*}$ & $4.44^{* *}$ & $6.42^{* *}$ & $4.60^{* *}$ & $9.31^{* *}$ & $6.37^{* *}$ & $3.62^{* *}$ & $12.51^{* *}$ & 1.59 \\
\hline & & $\mathrm{F}_{2}$ & $2.49^{* *}$ & 0.99 & $2.09^{*}$ & $1.99^{*}$ & 1.27 & 0.88 & 0.59 & 1.64 & 1.63 & 1.35 \\
\hline \multicolumn{13}{|l|}{ GC } \\
\hline \multirow[t]{2}{*}{$\sigma^{2} \mathrm{GCA} / \sigma^{2} \mathrm{SCA}$} & & $\mathrm{F}_{1}$ & -0.18 & 0.22 & -0.17 & -0.15 & 0.10 & -0.01 & -0.16 & 0.31 & 0.11 & 0.02 \\
\hline & & $\mathrm{F}_{2}$ & 0.00 & -37.02 & 0.03 & 0.33 & 0.34 & -1.44 & -0.09 & -0.07 & 0.34 & 0.24 \\
\hline \multirow[t]{2}{*}{$\sigma^{2} \mathrm{~A}$} & & $\mathrm{~F}_{1}$ & 0.12 & 9.89 & -4.4 & -0.92 & 24.44 & -0.68 & -16.84 & 10.44 & 5567.03 & 0.18 \\
\hline & & $\mathrm{F}_{2}$ & 0.00 & 6.26 & 0.13 & 0.15 & 5.67 & 12.95 & 1.49 & -0.76 & 847.92 & 0.43 \\
\hline \multirow[t]{2}{*}{$\sigma^{2} \mathrm{D}$} & & $F_{1}$ & -0.84 & 39.22 & 25.96 & 5.92 & 240.21 & 147.98 & 104.87 & 39.45 & 49356.53 & 7.38 \\
\hline & & $\mathrm{F}_{2}$ & 0.46 & -0.19 & 3.94 & 0.44 & 16.49 & -8.96 & -16.92 & 10.52 & 2491.09 & 1.75 \\
\hline \multirow[t]{2}{*}{$\sigma^{2} \mathrm{E}$} & & $\mathrm{F}_{1}$ & 0.58 & 15.73 & 1.20 & 0.25 & 20.43 & 4.84 & 4.85 & 3.18 & 1199.01 & 2.63 \\
\hline & & $\mathrm{F}_{2}$ & 0.07 & 9.52 & 0.79 & 0.12 & 20.09 & 22.45 & 12.65 & 8.28 & 3002.30 & 2.28 \\
\hline \multirow[t]{2}{*}{$\mathrm{H}^{2}$} & & $\mathrm{~F}_{1}$ & 0.18 & 0.76 & 0.96 & 0.96 & 0.92 & 0.97 & 0.96 & 0.94 & 0.98 & 0.74 \\
\hline & & $\mathrm{F}_{2}$ & 0.87 & 0.39 & 0.84 & 0.83 & 0.52 & 0.36 & 0.11 & 0.56 & 0.53 & 0.49 \\
\hline \multirow[t]{2}{*}{$h^{2}$} & & $F_{1}$ & 0.15 & 0.15 & 0.00 & -0.08 & 0.08 & -0.004 & -0.008 & 0.20 & 0.10 & 0.02 \\
\hline & & $\mathrm{F}_{2}$ & 0.00 & 0.39 & 0.03 & 0.21 & 0.13 & 0.36 & 0.11 & -0.008 & 0.13 & 0.10 \\
\hline \multirow[t]{2}{*}{ CLV (\%) } & & $F_{1}$ & 20.26 & 37.51 & 4.84 & 10.71 & 36.30 & 26.22 & 8.72 & 32.48 & 30.02 & 22.16 \\
\hline & & $\mathrm{F}_{2}$ & 25.64 & 35.73 & 31.42 & 43.68 & 35.21 & 20.58 & 17.53 & 25.44 & 35.20 & 32.24 \\
\hline \multirow[t]{2}{*}{ CTV (\%) } & & $\mathrm{F}_{1}$ & 19.88 & 5.08 & 12.08 & 6.71 & 4.15 & 6.69 & 7.61 & 17.53 & 13.07 & 12.29 \\
\hline & & $\mathrm{F}_{2}$ & 5.81 & 13.00 & 3.91 & 3.66 & 4.05 & 29.14 & 21.93 & 6.10 & 4.05 & 5.18 \\
\hline $\mathrm{CL} \times \mathrm{TV}(\%)$ & & $\mathrm{F}_{1}$ & 59.86 & 57.41 & 83.08 & 82.58 & 59.55 & 67.09 & 83.66 & 49.99 & 56.91 & 65.56 \\
\hline & & $\mathrm{F}_{2}$ & 68.55 & 51.26 & 64.67 & 52.66 & 60.74 & 50.28 & 60.54 & 68.46 & 60.75 & 62.57 \\
\hline
\end{tabular}

${ }^{*} \mathrm{P}<0.05,{ }^{* *} \mathrm{P}<0.01$ (SOV: Source of variation; DF: Degree of freedom; PR: Protein rate; SDS: Sedimentation value; WG: Wet gluten; DG: Dry gluten; BEM: Brebender equivalent at maximum torque; PMT: Peak maximum time; AM: torque $15 \mathrm{~s}$ before maximum; PM: torque 15 s after maximum; AE: Energy; WA: Water absorption; GC: Genetic components; GCA: General combining ability; SCA: Specific combining ability; A: additive; D: Dominance; $\mathrm{H}^{2}$ : Broad sense heritability; $\mathrm{h}^{2}$ : Narrow sense heritability; CLV: Contribution of lines variance; CTV: Contribution of testers variance; $\mathrm{CL} \times \mathrm{TV}$ : Contribution of line $\mathrm{x}$ tester interaction variance) 
The contributions to total variances of lines (CLV), testers (CTV), and "Line $\times$ Tester" interaction $(\mathrm{CL} \times \mathrm{CTV})$ varied for examined traits in both generations. The $\mathrm{CL} \times \mathrm{CTV}$ to all properties were defined as the highest in both generations. The $\mathrm{CL} \times \mathrm{CTV}$ increased in the $\mathrm{F}_{2}$ generations for PR, BEM, PM and AE values. The CLV or CTV was generally inversely varied. Namely, if the CLV decreased in $F_{2}$, the CTV increased. However, both CLV and CTV increased in the $F_{2}$ for AM value, while they decreased for BEM and PM values. This indicates that the distribution of parental alleles reshapes in progenies as the generations progress, because $F_{1}$ is completely heterozygote, while $\mathrm{F}_{2}$ is the first segregating generation.

When the GCA / SCA ratio is less than one and negative, it is interpreted by the presence of "additive $\mathrm{x}$ dominance" gene interactions (Falconer and Mackay, 1996). The ratio of the GCA and SCA variance estimates for examined traits indicated that "additive $\times$ dominance" gene interaction was available for PR, WG, DG, PMT, and $A M$ in the $F_{1}$, while dominant gene effects were dominated in all other traits. The situation in the $F_{2}$ was different because of re-regulation of genes. Additive and dominant genes were equally effective on the protein rate. "Additive $\times$ dominance" and epistatic gene interaction was present on the values of AM, PM, SDS, and PMT in the $F_{2}$, while the dominant gene effects continued to predominate on other properties. The prominence of dominant genes was confirmed by the variances of additive and dominance. In the $\mathrm{F}_{1}$ generation, the $\mathrm{H}^{2}$ mostly indicated a moderate and high degree of heritability. It was expected that the value of heritability in the $F_{2}$ would decrease because the homozygosity in the population increased. The $\mathrm{h}^{2}$ was found very low due to the prominent dominant genes. It was also found that some traits had a negative heritability degree. The reason is that dominant and epistasis variances in total genetic variance are larger than the additive variance. Nonadditive effects can be superior due to a high degree of dispersion of increasing alleles between parents. Moreover, these mentioned results suggest that it may be due to the epistatic incompatibilities between alleles at two or more loci (Boeven et al., 2020).

Dominance, one component of non-additive genetic variance, is a fundamental cause of inbreeding depression while epistasis occurs depending on the genetic background and environmental conditions (Novoselovic et al., 2004). The results of the calculated genetic parameters were based on the fact that the traits examined have a complex genetic structure that is highly influenced by the environment and managed by a large number of alleles. Therefore, the selection for these traits should be postponed to further generations. Patel et al. (2018) detected non-additive gene effects and low heritability for PR, SDS, and gluten amount. The most important quality criteria in wheat are PR, SDS, and gluten amount, and these traits are managed by many genes, have low heritability and are affected by environmental conditions. All of these make it difficult to transfer from one progeny to another. However, testing with a low number of samples by rapid analysis techniques has revealed important opportunities in quality breeding.

\section{General combining ability of 11 parents for basic quality traits}

The GCA value is a parameter commonly used for parental selection in hybridization breeding. The ability to transmit the desired performance to the hybrid progeny of a genotype is defined as the combining ability (Falconer and Mackay, 1996). It is possible to select the characteristics which are not affected by environmental conditions according to the parental observation values without the need for intensive biometric-genetic evaluations. Although the quality characteristics of bread wheat are heritable, they are also affected by environmental conditions.

Figure 1 shows the average observation values and GCA effects of the examined characteristics of the parents used in the study. The PR values and the combining ability effects of parents were found very close to each other in both generations. The DH22 line with the highest observation value also had the highest positive GCA effect and could be an ideal parent to develop a cultivar with high protein. Even if Bezostaja-1 genotypes had high GCA in the $F_{1}$, they could not maintain these attributes in the $F_{2}$. Bezostaja- 1 is an indispensable parent in breeding programs that generally aim to improve protein quality (Horvat et al., 2006; Mladenov et al., 2011). However, the DH20 and DH22 lines may be competitors by having both high observation values and GCA effects.

The high SDS shows that the amount and quality of gluten are high. Generally, there is a positive relationship between PR, gluten content and SDS (Katyal et al., 2016). In this study, protein, gluten, and sedimentation values did not parallel each other. The highest SDS value was observed in Bezostaja-1 between testers and in DH16 between lines. The GCA effects were acceptable in DH20, DH21 and Bezostaja-1 genotypes, considering both generations.

It has been reported that the bread wheat quality will be acceptable with a WG amount over of $28 \%$. The amount of DG is $1 / 3$ of the amount of WG (Egesel et al., 2009). In this study, WG and DG values nearly of all parents were above the desired values. When the GCA effects were examined, the DH20 and DH22 lines had high values in both generations and therefore, emerged as suitable parents for breeding studies intended for increased gluten content.

\section{General combining ability of 11 parents for GlutoPeak traits}

Figure 2 shows the GCA of 11 parents for Glutopeak traits. BEM value corresponding to the maximumrecorded torque occurring as gluten aggregates is high in good quality genotypes (Amoriello et al., 2016). Genotypes DH18, DH21, Bezostaja-1, Harmankaya-99, and Kate A-1 were prominent in terms of BEM value. It was satisfactory that the GCA effects of these genotypes 
(except Bezostaja-1) were positive. In addition, lines effects in both generations.

DH20 and DH22 should be considered with high GCA

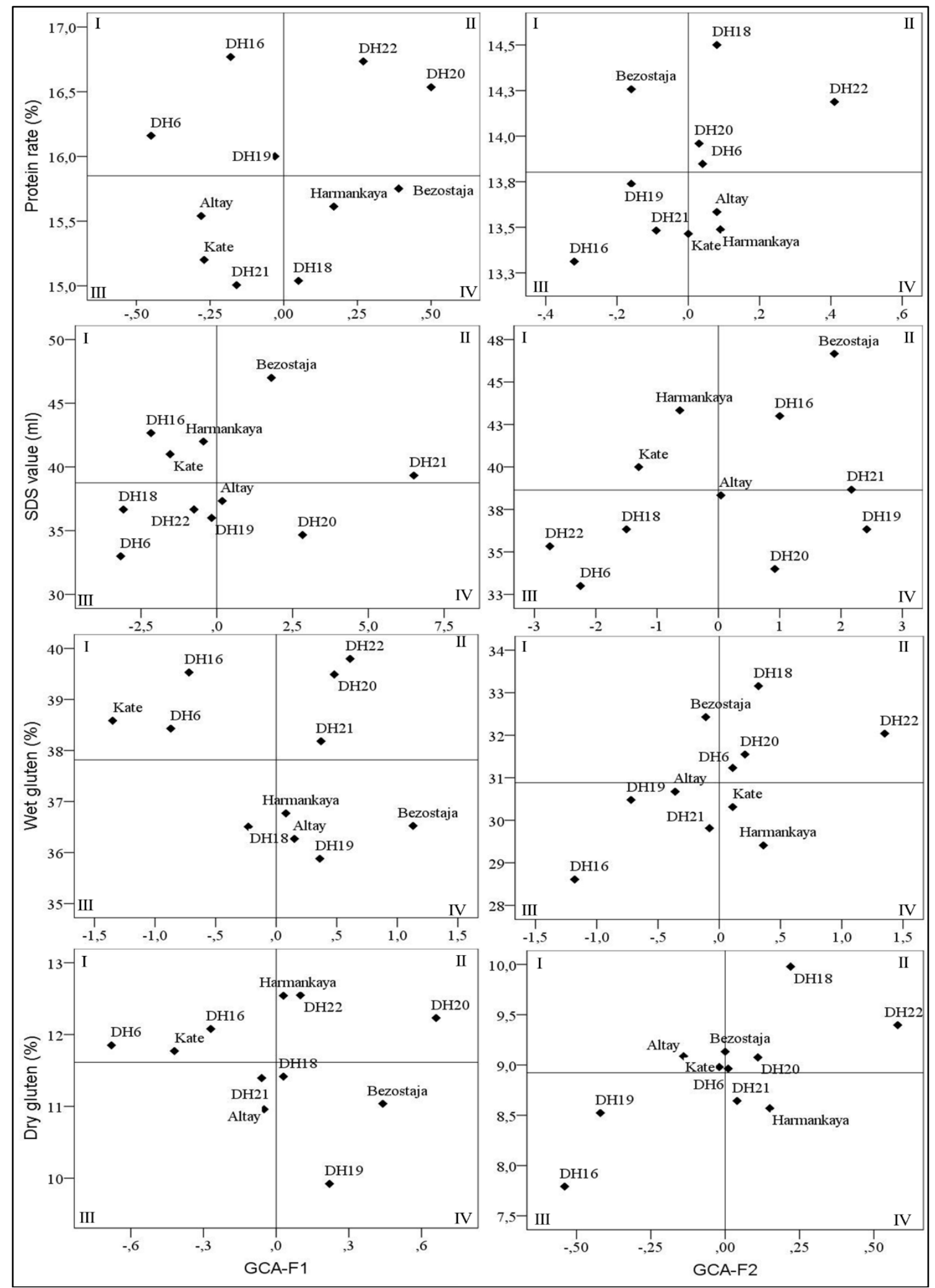

Figure 1. Mean performance and general combining ability (GCA) of 11 parents for some quality parameters (I: good performance/poor combiner, II: good performance/good combiner, III: poor performance/poor combiner, IV: poor performance/good combiner) 


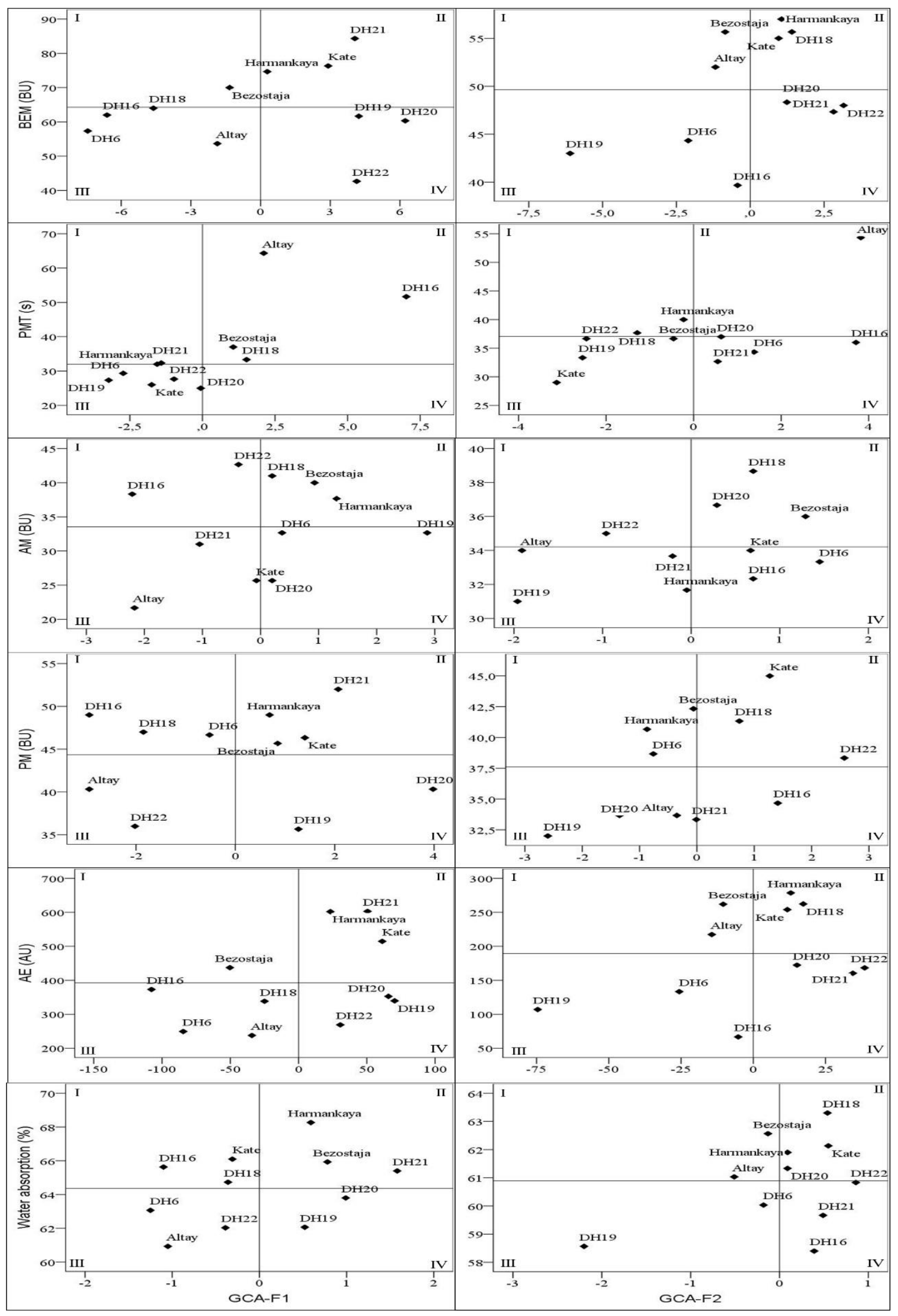

Figure 2. Mean performance and general combining ability (GCA) of 11 parents for GlutoPeak traits (I: good performance/poor combiner, II: good performance/good combiner, III: poor performance/poor combiner, IV: poor performance/good combiner) 
The PMT value corresponds to the time until the maximum torque is reached, and it is an indicator of gluten aggregation kinetics (Amoriello et al., 2016). The decrease in PMT indicates increasing protein and gluten content (Sissons, 2016; Rakita et al., 2018). The PMT values of parents as means changed from 27.50 (Kate A1) to 59.33 (Altay-2000). Genotypes DH19 and Kate A-1 may be suitable parents to reduce PMT with negative GCA effects.

The AM value shows a good correlation with the loaf volume and a low AM value is an indicator of weak gluten structure. AM value is generally above 20 in bread flour (Bouachra et al., 2017). All of the parents are genotypes with good bread quality. Parents with positive combining ability have the competence to transfer the desired AM value to their offspring. DH18 and Bezostaja-1 genotypes should be particularly emphasized.

The PM value indicates the weakening of gluten along with continued mixing and it is generally high in flatbread (yufka) and bread flour, while low in biscuit flour (Karaduman et al., 2015). All parents are suitable to make high-quality yufka and bread according to PM value. The Kate A-1 with the highest PM value had a high and positive GCA effect and continued this in the $\mathrm{F}_{2}$ generation. Then, the lines DH18, DH21, and DH22 should be followed for this trait.

The value of AE proposed for standard flour is ranged 160-200 $\times 10^{-4} \mathrm{~J}$ (Bordes et al., 2008). Determined AE values of nearly all parents in this study were higher than standard flour. DH18, DH21, Harmankaya-99, and Kate A-1 genotypes could form the strong dough. The aforementioned genotypes had combining ability effects that could transfer their strong dough-forming capability to their generations. The $\mathrm{DH} 20$ and $\mathrm{DH} 22$ lines are also parents that could be used to obtain a medium-strength dough.

Water absorption is the water amount required for a particular flour weight to obtain dough of desired consistency (Aydogan et al., 2015). High WA is desired. Although the WA values were found very close to each other, the GCA effects were different. All genotypes except DH6 were qualified parents for the desired WA.

Genotype selection based on both the GlutoPeak observation values and the effects of the combining ability will provide new genetic resources to breeding programs intended for the development of these characteristics. DH20, DH21, DH22, Bezostaja-1, Harmankaya-99, and Kate A-1 genotypes are fit for this purpose.

\section{Specific combining ability of 28 "Line $\times$ Tester" bread wheat crosses for basic quality traits}

Figure 3 shows the SCA of 28 "Line $\times$ Tester" bread wheat crosses for some quality parameters. In hybrids, "DH20 $\times$ Harmankaya-99" had the highest value in the $F_{1}$ generation with $17.06 \%$. In the $\mathrm{F}_{2}$ generation, the PR between hybrids changed between $13.10 \%$ $($ DH6 $\times$ Bezostaja-1) and $14.98 \% \quad(\mathrm{DH} 22 \times$ Kate A-1). According to Thorwarth et al. (2018), PR of $F_{1}$ hybrids has lower mean values compared to their parents while Al-Naggar et al. (2015) reported that they have higher PR than their parents. In this study, hybrids were generally among parental values. "DH19×Harmankaya-99", "DH20×Bezostaja-1" and "DH21×Altay-2000" are promising combinations with high observation values and positive SCA effects in both generations. Hybrids (DH18 $\times$ Kate A-1, DH19×Bezostaja-1, and DH20 $\times$ Harmankaya-99) with superior $F_{1}$ performance and low $\mathrm{F}_{2}$ performance or hybrids (DH6 $\times$ Altay-2000, DH6 $\times$ Harmankaya-99, DH22 $\times$ Kate A-1) with low $F_{1}$ performance but high $\mathrm{F}_{2}$ performance should also be followed for several generations.

The SDS was the highest in the "DH21×Altay-2000" $(54.33 \mathrm{ml})$ in the $\mathrm{F}_{1}$, whereas the highest value was found in the "DH21×Bezostaja-1" $(45.33 \mathrm{ml})$ in the $F_{2}$. While SDS of all hybrids decreased in the $\mathrm{F}_{2}$ generation, the SDS value of "DH16×Altay-2000" increased. The SCA effects of hybrids were as follows: $-6.88(\mathrm{DH} 20 \times$ Bezostaja-1) 7.79 (DH19 $\times$ Bezostaja- $)$ in the $F_{1}$ and -3.98 $\left(\right.$ DH18 $\times$ Bezostaja-1) $-5.02\left(\right.$ DH21 $\times$ Bezostaja-1) in the $F_{2}$.

The values of WG and DG were mostly similar. The WG values were found to be lower in the $F_{2}$ generation and the rate of DG was lower in the same way. Eighteen hybrids in the $F_{1}$ had a positive SCA effect, whereas 12 hybrids had a positive SCA effect in the $\mathrm{F}_{2}$ for both traits. Both high performance and acceptable combining ability were found in "DH22×Kate A-1", "DH21×Altay-2000", "DH20×Bezostaja-1", and "DH6 $\times$ Harmankaya-99" in both generations for WG and DG value. Dry gluten can be accepted as a direct indicator of flour strength and breadmaking potential by correlating with crude protein (Pasha et al., 2007). Hybrids that stand out in terms of DG values are promising as quality bread wheat genotypes.

\section{Specific combining ability of 28 "Line $\times$ Tester" bread wheat crosses for GlutoPeak traits}

The GlutoPeak method correlates most of the breadmaking quality characters (Marti et al., 2015; Bouachra et al., 2017; Rakita et al., 2018). In addition to the observed values of the genotypes in terms of GlutoPeak properties, knowing the combining abilities will make it easier to reveal those with high quality. The high BEM, AM, and PM values are indicated more gluten strength (Marti et al., 2015).

Figure 4 shows the SCA of 28 "Line $\times$ Tester" bread wheat crosses for GlutoPeak traits. The hybrids examined in the $\mathrm{F}_{1}$ generation were similar in terms of BEM and PM values. "DH20×Harmankaya-99" and "DH21×Altay2000", which show high observation and SCA values for all three values, are capable of high gluten resistance. Hybrids with superior performance and high combining ability due to changes in the distribution of alleles in combinations have taken place in different groups in the $\mathrm{F}_{2}$. However, there were still combinations that are capable of maintaining high gluten resistance, namely "DH16×Kate A-1", "DH22×Kate A-1" and "DH21×Altay-2000". 


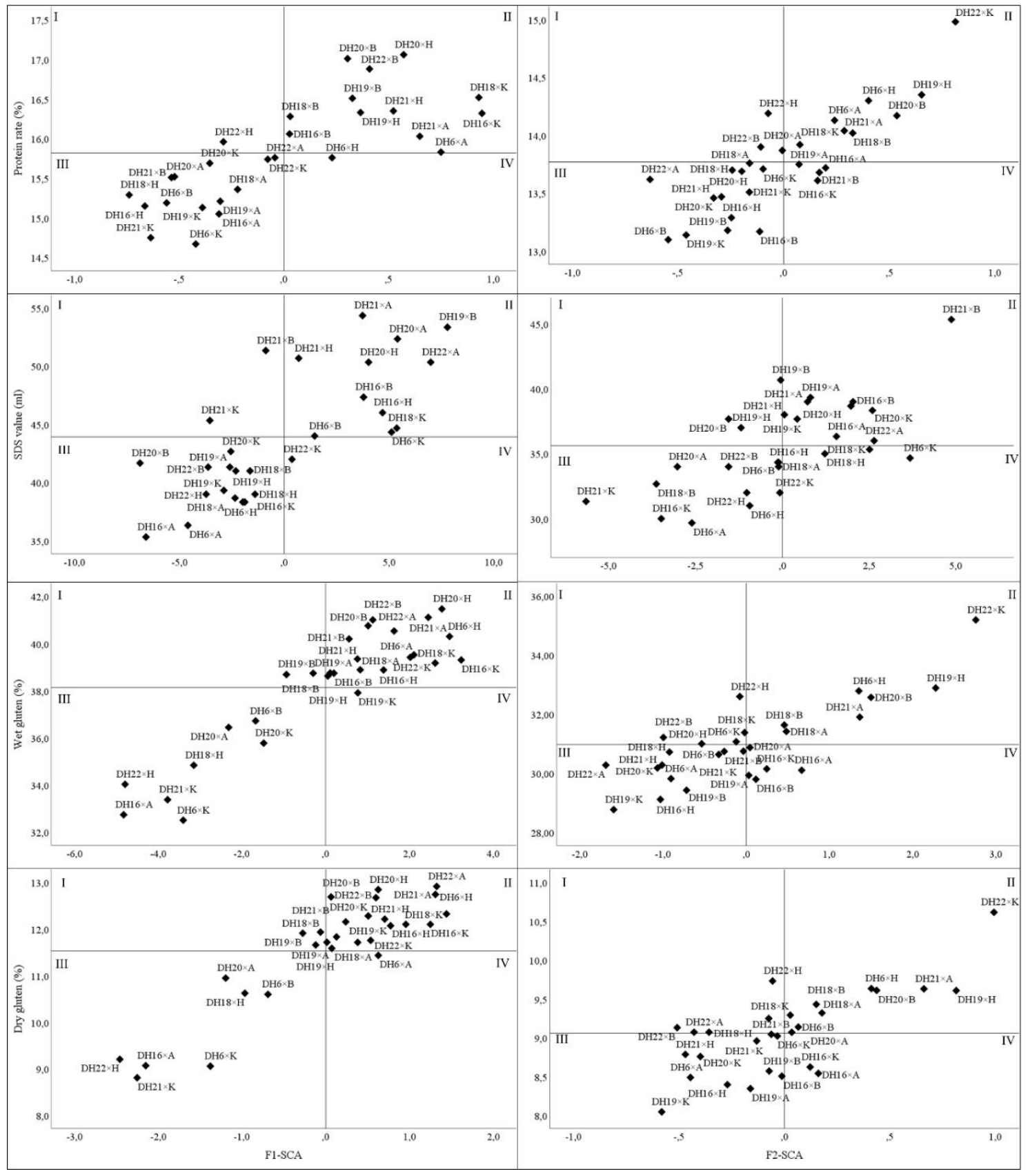

Figure 3. Mean performance and specific combining ability (SCA) of 28 "Line×Tester" bread wheat crosses for some quality parameters (I: good performance/poor combiner, II: good performance/good combiner, III: poor performance/poor combiner, IV: poor performance/good combiner; Genotype codes: A: Altay, B: Bezostaja, H: Harmankaya, K: Kate) 


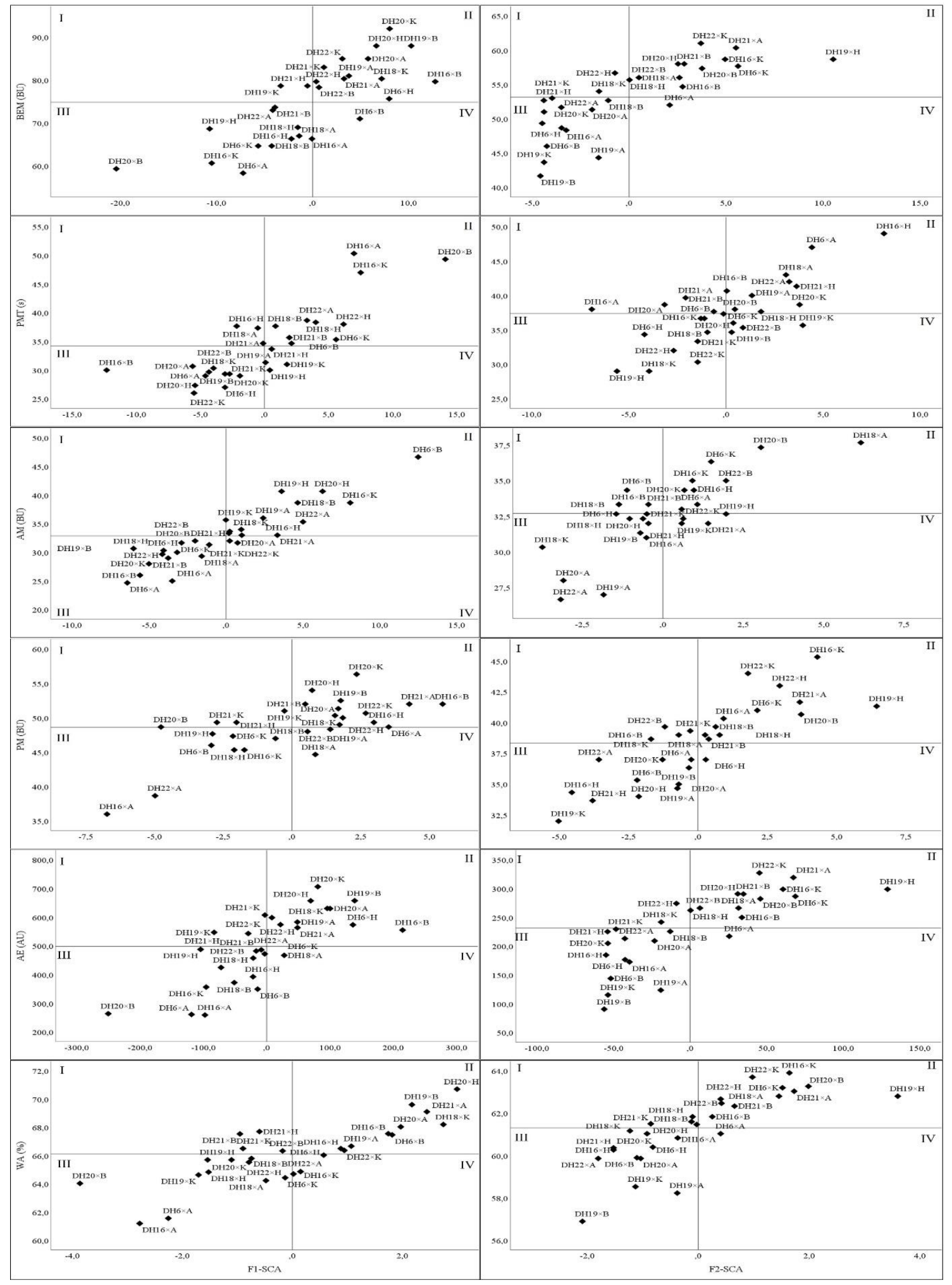

Figure 4. Mean performance and specific combining ability (SCA) of 28 "Line×Tester" bread wheat crosses for Gluto-Peak traits (I: good performance/poor combiner, II: good performance/good combiner, III: poor performance/poor combiner, IV: poor performance/good combiner; Genotype codes: A: Altay, B: Bezostaja, H: Harmankaya, K: Kate)

The value of PMT, which is associated with the dough kneading time, was high in "DH6 $\times$ Kate A-1", "DH18×Harmankaya-99", "DH20×Bezostaja-1" and "DH22×Altay-2000" and their positive combining abilities in both generations seem to be suitable for longprocess bread quality with longer kneading time.

Considering the classification of Bordes et al. (2008), all genotypes were higher than medium-strong dough and 
standard flour in the $\mathrm{F}_{1}$. "DH16 $\times$ Harmankaya-99", "DH6×Harmankaya-99", "DH16×Altay-2000", "DH6×Bezostaja-1", "DH19×Kate A-1", "DH19×Altay2000" and "DH19 $\times$ Bezostaja-1" with weak and medium dough characteristics and below the standards of flour in the $F_{2}$ also had negative SCA. However, "DH20×Harmankaya-99", "DH16×Bezostaja-1" and "DH21×Altay-2000", all showing high AE and SCA values in both $F_{1}$ and $F_{2}$, should be followed for this trait.

Bread-making flours should have a high WA capacity so that the dough and bread yield will be relatively high (Ma et al., 2007). All of the hybrids examined in the study had an acceptable WA capacity. Hybrids such as "DH20×Harmankaya-99", "DH21×Altay-2000", "DH16×Bezostaja-1" and "DH22×Kate A-1" with high and positive SCA are promising for this trait.

In the examined population, "DH16×Bezostaja-1", "DH20×Bezostaja-1", "DH20×Harmankaya-99", "DH21×Altay-2000" and "DH22×Kate A-1" are promising combinations for all traits according to observation values and SCA effects.

\section{CONCLUSION}

In this study, the SCA effect indicated non-additive gene effects were prominent in all examined traits. It can be proposed that postpone the selection to the next generations to avoid loss of superior genotypes. However, selection may be started in the $F_{2}$ generation for protein rate, SDS sedimentation value, gluten content, and GlutoPeak traits such as PMT, AM, and PM depending on epistasis. Even though there was a remarkable decrease in the magnitude of the SCA in the $F_{2}$ population in most combinations, an opportunity could still be obtained for the selection of best quality genotypes. The data obtained from this study are valid for the current population and environmental conditions. It should be supported with various research in populations that will be created with different genotypes to characterize different gene interactions.

\section{ACKNOWLEDGEMENT}

This research supported by the Scientific Research Projects Commission of Eskisehir Osmangazi University (project no: 201723009).

\section{LITERATURE CITED}

AACC. 2010. Approved Methods of Analysis, 11th Ed. Method 39-01.01. Evaluation of NIR instrument calibration. Approved November 17, 2010. Cereals \& Grains Association, St. Paul, MN, U.S.A.

Al-Naggar, A., R. Shabana, M. M. Abd El-Aleem and A. ElRashidy Zainab. 2015. Diallel analysis of wheat grain protein content and yield in $F_{1}$ and $F_{2}$ generations under contrasting nitrogen conditions. American Research Journal of Agriculture 1(4): 12-29.

Amoriello, T., V. Turfani, V. Galli, F. Mellara and M. Carcea. 2016. Evaluation of new viscometer performance in predicting the technological quality of soft wheat flour. Cereal Chemistry 93: 364-368.

Aydogan, S., M. Sahin, A. G. Akcacik, S. Hamzaoglu and S. Taner. 2015. Relationships between Farinograph Parameters and Bread Volume, Physicochemical Traits in Bread Wheat Flours. Journal of Bahri Dagdas Crop Research 3(1): 14-18.

Baslar, M. and M. F. Ertugay. 2011. Determination of protein and gluten quality-related parameters of wheat flour using near-infrared reflectance spectroscopy (NIRS). Turkish Journal of Agriculture and Forestry 35(2): 139-144.

Boeven, P. H., Y. Zhao, P. Thorwarth, F. Liu, H. P. Maurer, M. Gils and V. Mirdita. 2020. Negative dominance and dominance-by-dominance epistatic effects reduce grain-yield heterosis in wide crosses in wheat. Science Advances 6 (24): eaay4897.

Bordes, J., G. Branlard, F. X. Oury, G. Charmet and F. Balfourier. 2008. Agronomic characteristics, grain quality and flour rheology of 372 bread wheats in a worldwide core collection. Journal of Cereal Science 48(3): 569-579.

Bouachra, S., J. Begemann, L. Aarab and A. Hüsken. 2017. Prediction of bread wheat baking quality using an optimized GlutoPeak ${ }^{\circledR}$-Test method. Journal of Cereal Science 76: 816.

Egesel, C., F. Kahrıman, S. Tayyar and H. Baytekin. 2009. Interrelations of flour quality traits with grain yield in bread wheat and choosing suitable cultivars. Anadolu Journal of Agricultural Science 24(2): 76-83.

Falconer, D.S. and T.F.C. Mackay. 1996. Introduction to Quantitative Genetics. Fourth Edition. Longman, ISBN: 0582-23302-5, $464 \mathrm{p}$.

Fu, B.X., K. Wang and B. Dupuis. 2017. Predicting water absorption of wheat flour using high shear-based GlutoPeak test. Journal of Cereal Science 76: 116-121.

Gabriel, D., C. Pfitzner, N. U. Haase, A. Hüsken, H. Prüfer, J. M. Greef and G. Rühl. 2017. New strategies for a reliable assessment of baking quality of wheat-Rethinking the current indicator protein content. Journal of Cereal Science 77: 126-134.

Horvat, D., Z. Jurković, G. Drezner, G. Šimić, D. Novoselović and K. Dvojković. 2006. Influence of gluten proteins on technological properties of Croatian wheat cultivars. Cereal Research Communications 34(2-3): 1177-1184.

Hruskova, M. and O. Famera. 2003. Prediction of wheat and flour Zeleny sedimentation value using NIR technique. Czech Journal of Food Science 21: 91-96.

Jirsa, O. and M. Hruskova. 2005. Characteristics of fermented dough predicted by using the NIR technique. Czech Journal of Food Science 23: 184-189.

Karaduman, Y., A. Akin, S. Turkolmez and Z. S. Tunca. 2015. Investigating the availability of glutopeak parameters for evaluation of gluten quality in bread wheat breeding programs. Journal of Field Crops Central Research Institute. 24(1): 65-74.

Katyal, M., A. S. Virdi, A. Kaur, N. Singh, S. Kaur, A. K. Ahlawat and A. M. Singh. 2016. Diversity in quality traits amongst Indian wheat varieties I: flour and protein characteristics. Food Chemistry 194: 337-344.

Kempthorne, O. 1957. An Introduction to Genetic Studies. John Wiley and Sons Inc., New York. pp. 265-270.

Kutlu, I., M. Carikci, O. Yorgancilar, A. Yorgancilar, Y. Karaduman and Z. Sirel. 2017. Glutenin subunits, gliadin patterns and glutopeak characteristics of Turkey's doubled haploid wheat lines. Pakistan Journal of Botany 49(5): 19251932.

Ma, W., M. W. Sutherland, S. Kammholz, P. Banks, P. Brennan, W. Bovill and G. Daggard. 2007. Wheat flour protein content and water absorption analysis in a doubled haploid population. Journal of Cereal Science 45(3): 302-308.

Marti, A., E. Augst, S. Cox and P. Koehler. 2015. Correlations between gluten aggregation properties defined by the GlutoPeak test and content of quality-related protein 
fractions of winter wheat flour. Journal of Cereal Science 66 89-95.

Mladenov, N., N. Hristov, A. Kondic-Spika, V. Djuric, R. Jevtic and V. Mladenov. 2011. Breeding progress in grain yield of winter wheat cultivars grown at different nitrogen levels in semiarid conditions. Breeding Science 61(3): 260-268.

Nathan, S. N., A. A. Swelam, E. M. I. Mahgoub and A. H. Fayed. 2011. Genetical analysis of SDS-sedimentation volume and grain protein content in Egyptian bread wheat varieties. Zagazig Journal of Agricultural Research 38(2): 371-384.

Novoselovic, D., M. Baric, G. Drezner, J. Gunjaca and A. Lalic. 2004. Quantitative inheritance of some wheat plant traits. Genetics and Molecular Biology 27(1): 92-98.

Pasha, I., F. M. Anjum, M. S. Butt and J. I. Sultan. 2007. Gluten quality prediction and correlation studies in spring wheats. Journal of Food Quality 30(4): 438-449.

Patel, N. A., N. D. Dholariya, I. R. Delvadiya and V. R. Akbari. 2018. Genetic analysis of grain yield, its components and quality parameters in durum wheat (Triticum durum Desf.) over environments. International Journal of Pure Applied Bioscience 6(2): 523-532.

Pena, R.J., A. Amaya, S. Rajaram and A. Mujeeb-kazi. 1990. Variation in quality characteristics associated with some spring $1 \mathrm{~b} / 1 \mathrm{r}$ translocation wheats, Journal of Cereal Sciences 12: $105-112$.

Rakita, S., L. Dokić, T. Dapčević Hadnađev, M. Hadnađev and A. Torbica. 2018. Predicting rheological behavior and baking quality of wheat flour using a GlutoPeak test. Journal of Texture Studies 49(3): 339-347.

Rodríguez, F., G. Alvarado, Á. Pacheco, J. Crossa and J. Burgueño. 2015. AGD-R (Analysis of genetic designs with $\mathrm{R}$ for Windows) version 4.0. International Maize and Wheat Improvement Center (CIMMYT).

Sissons, M. 2016. GlutoPeak: A breeding tool for screening dough properties of durum wheat semolina. Cereal Chemistry 93(6): 550-556.

Thorwarth, P., H. P. Piepho, Y. Zhao, E. Ebmeyer, J. Schacht, R. Schachschneider and C. F. H. Longin. 2018. Higher grain yield and higher grain protein deviation underline the potential of hybrid wheat for a sustainable agriculture. Plant Breeding 137(3): 326-337.

Wang, K., B. Dupuis and B. X. Fu. 2017. Gluten aggregation behavior in high-shear-based GlutoPeak test: Impact of flour water absorption and strength. Cereal Chemistry 94(5): 909915.

Wieser, H. 2007. Chemistry of gluten proteins. Food Microbiology 24: 115-119. 